Article

\title{
Towards a Heritage-Led Sustainable Post-Conflict Reconciliation: A Policy-Led Perspective
}

\author{
Ataa Alsalloum ${ }^{1, *(1)}$ and Andre Brown ${ }^{2, *}$ \\ 1 School of Architecture, The University of Liverpool, Leverhulme Building, Liverpool L69 7ZN, UK \\ 2 School of Architecture (Te Kura Waihanga), Victoria University of Wellington, Wellington 6140, New Zealand \\ * Correspondence: ataa2@liverpool.ac.uk (A.A.); andre.brown@vuw.ac.nz (A.B.)
}

Received: 13 January 2019; Accepted: 14 March 2019; Published: 20 March 2019

\begin{abstract}
In today's context, threats to heritage sites posed by armed conflicts are prevalent. This article argues for an urgently needed framework, based on authoritative heritage policy documents, to guide sustainable reconciliation in such circumstances. The methodological approach proposed derives from a content analysis strategy that investigated a selected list of documents. Key extractions are then synthesised to develop useful recommendations for sustainable post-conflict reconciliation in heritage contexts. This conceptual framework also helps to achieve the potential re-nomination of any reconstructed sites which, in turn, provides both additional robust protection of heritage values, and supports sustainable development. This article presents the first part of a broader research study and is intended to communicate the results to a multi-faceted international audience including stakeholders, along with policy and decision makers in the world heritage field. The application of the proposed framework to the world heritage cities of Damascus and Aleppo is the subject of the second part of this research and is presented in a subsequent paper in this special issue of the journal Sustainability.
\end{abstract}

Keywords: cultural heritage; heritage policies; post-conflict; reconciliation; sustainable reconstruction; sustainable reconciliation; heritage values

\section{Introduction}

The responsibility for the protection of nearly 1100 heritage sites recognised on the UNESCO world heritage list today is shared by both national and international authorities. Such listings imply a duty for safeguarding these cultural, natural, or mixed assets for present and future generations. Cultural heritage has become a key factor in achieving sustainable urban development, particularly with its contribution to boosting the measures of liveability and sustainability [1]. Such heritage assets have, sadly, also become a target for destruction in conflict situations, primarily because of their attributed values [2].

Clear strategies for manging the sustainability of these assets, to optimize their value, while concurrently safeguarding their cultural significance, have not yet been fully effective in peacetime [3]. However, the challenge of reconstruction in post-conflict situations, where the cultural heritage asset and its values have been partially or totally lost, has been even more controversial. The displacement of the connected communities, in addition to differing societal interests that emerge from conflict situations add particular challenges $[2,4,5]$.

Recent devastating damage to heritage sites, as a result of the armed conflict in the Middle East and North Africa (MENA) region, have raised major concerns among the international communities. Consequently, a variety of heritage policies and documents has been issued. These are built on the legacy of previous key heritage guidance documents and are tailored to address the emerging challenges of reconstruction and recovery. The main aim has been to safeguard the remaining heritage 
assets and values, simultaneously enabling the repositioning of this heritage as a driver for sustainable development and as an important component in peace building. The ultimate objective is to attain the 17 sustainable development goals (SDGs) specified by the 2030 agenda for sustainable development promulgated by the United Nations (UN) in 2015. Within SDG 11 (sustainable cities), the agenda acknowledges the importance of safeguarding natural and cultural heritage; it also places culture as a key driver within the relevant targets [6].

Inherently, despite the fundamental importance of these constructive responses to the current challenges, these international contributions have not fully addressed key clarifications in relation to heritage values. Additionally, the gap between theory and practice, at both international and local levels, in terms of sustaining or commemorating heritage assets, remains substantial. Responding to this, the ultimate aim of our research is to establish an authoritative framework that acts as guidance for a heritage-led sustainable reconciliation strategy, as an urgent reaction to the current destruction of heritage properties and the displacement of people in the MENA region.

The research is presented in two papers. The first, the current paper, presents the theoretical part, and the second paper tests the conceptual results against two case studies in Syria, the world heritage cities of Aleppo and Damascus. Both papers are presented in this special issue of the journal Sustainability. The present paper aims to:

- define an appropriate approach for reconstruction that is based on sustaining the heritage values and maintaining the continuity of both role and function of heritage assets in the life of its community-in line with Sustainable Development Goals (SDGs), particularly Goal 11 (sustainable cities and communities);

- extract useful identification of the total heritage values attributed to heritage areas, cities and/or urban contexts by analysing the most relevant key heritage policies;

- propose clarifications and guidance to be integrated into recent national and international heritage policies aimed at sustainable reconciliation;

while the second paper, aims to:

- establish a conceptual Framework for a reconstruction style that can be embedded into recently promulgated national and international heritage documents;

- test this Framework on two cases in Syria; Old Damascus, and Old Aleppo.

- propose clarifications and guidance to be integrated into the national heritage policy for sustainable reconciliation in Syria.

Syria was chosen as the country under focus in our research because of its current situation. The country has already started its recovery process in peace areas, despite the continuity of the conflict in other parts of the country. Syria is a state party member of UNESCO and the country ratified the 1972 UNESCO Convention Concerning the Protection of Cultural and Natural Heritage in 1975.

Syria, as a state party also ratified other key documents, such as the Huge Convention with its two protocols 1954/1999 and the UNESCO 2003 Convention for the Safeguarding of the Intangible Cultural Heritage. More importantly, these policies have been the main source for the ongoing preparation of a local heritage policy document in Syria. However, the structural and textual ambiguities in these international policies have contributed to difficulties in utilising practical local directives, particularly in response to current substantial fabric destruction and population displacement. Consequently, our aim here is to contribute to shaping purpose-driven policy documents that incorporate and facilitate the application of international guidance.

Old Aleppo and Old Damascus represent examples of the heritage cities in the MENA region. Both cities represent different levels of destruction. Old Aleppo has been severely destroyed, while minor destruction has occurred in Old Damascus, so application to this pair of cases provides an opportunity to rigorously test the final recommendations of our research.

This paper initially presents the Syrian heritage context and local policies. Then, key recent international debates on reconstruction and reconciliation are visited. The methodology adopted, 
employing a content analysis (CA) applied to the selected heritage policies is then presented, followed by the results of that analysis. Discussions and reflections on findings are subsequently presented.

\subsection{Syria Context}

The lack of consistency in national and international heritage policies [7-9], in addition to a shortage of local documentation [10], has contributed to the loss of cultural heritage assets in historic and heritage areas in Syria in the pre-conflict era. This in turn has led to confusion in terms of reconstruction in the post-conflict epoch.

Syria hosts six cultural world heritage sites, as shown in Figure 1. Of these, the walled cities of Damascus and Aleppo are the only 'living heritage' sites and they claim to be among the oldest continuously inhabited cities in the world [11].

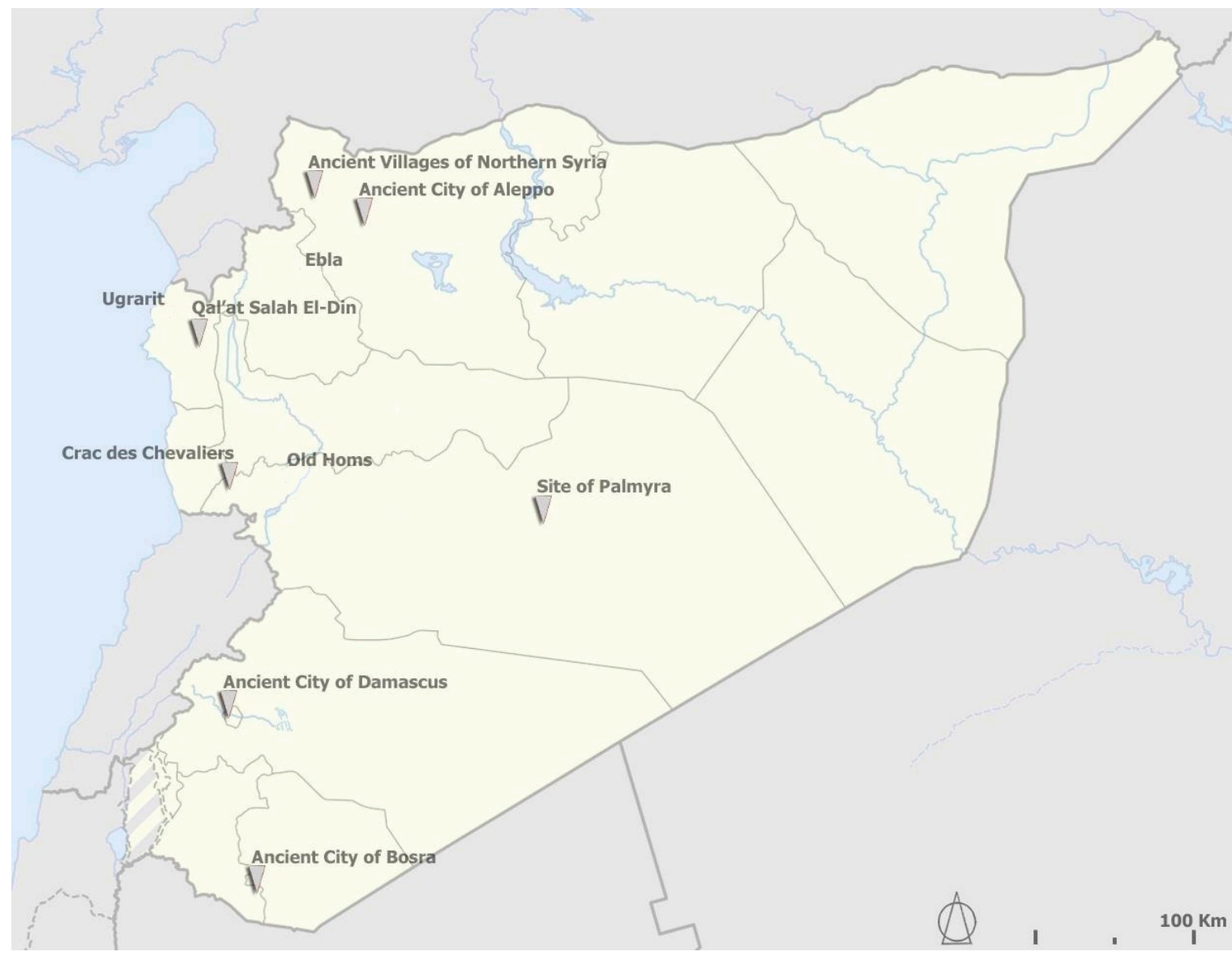

Figure 1. The six World Heritage Sites in Syria (extracted from Google Earth and Wikipedia).

There are also twelve sites on the World Heritage Tentative List [12]. This substantial collection of Tangible Cultural Heritage ( $\mathrm{TCH})$ assets is also home to diverse cultural environments that exhibit a vibrant range of Intangible Cultural Heritage (ICH) qualities. These qualities straddle all the domains in the 2003 UNESCO Convention for the Safeguarding of the Intangible Cultural Heritage, which was ratified by Syria in 2005. Somewhat surprisingly, the only tradition recognised by UNESCO as a living human heritage is falconry; though very recently, in November 2018, shadow play was inscribed on the list of intangible cultural heritage features in need of urgent safeguarding during the 13th session of the UNESCO committee meeting [13].

According to national and international reports, the level of destruction varies across the heritage sites. Old Aleppo and Palmyra have sites with the most extensive destruction; Bosra, Crac des 
Chevaliers, Qal'at Salah El-Din and the Ancient Villages of Northern Syria are moderately damaged, whilst Old Damascus is the least affected heritage city [14].

Nationally, the Antiquities Law No. 222 is the main policy regulating all heritage management issues, and has been in place since 1963. Since 2011, the Directorate-Generate of Antiquities and Museums (DGAM) has been working on developing a new policy: the Law for Protection, Management and Promotion of Cultural Heritage. This law revokes the previous Antiquities Law and exclusively guides all conservation activities, in Old Damascus.

The new document has not been officially published yet [15]. Its primary guidance provides general definitions of its terms in the preamble. These include inter alia heritage, conservation, authenticity and historic cities. The document is divided into eight chapters corresponding to general provisions, conservation issues and responsibilities, but reconstruction and restoration are overlooked. It also provides definitions of cultural heritage types in line with the UNESCO 1972 Convention and its operational guidelines, such as movable, immovable and intangible heritage. However, it identifies three sets of criteria for designation on the National Heritage List that are distinctive when compared to the 10 designation criteria contemplated by UNESCO. The criteria in this new document are 'historic' including the values relating to time, identity and character, 'educational' including the values covering aspects of education and creativity, and 'technical and artistic' including the values of aesthetic quality, rarity and public participation. The new document also provides possibilities of instituting criminal proceedings against those who commit cultural heritage violations.

In the light of the current destruction and initial attempts aimed at reconstruction, it is debateable whether this proposed heritage policy will be sufficient to guide the reconstruction of the cultural heritage, particularly in heritage cities, where heritage values play a vital role in the continuity and sustainability of all aspects of life. Similar statements in relation to the deficiency of national and international policies to respond to the current urgent needs for an inclusive reconstruction have been emphasised by various scholars (see $[8,16])$.

\subsection{International Debates}

Through the long history of civilisations, the question of how to reconstruct the built fabric of historic and heritage towns and cities has been a major concern in post-conflict and post-disaster situations. This debate can be simplified as three views that are broadly aligned with one of three over-arching approaches: reconstruction in the traditional style; reconstruction in a contemporary style or reconstruction in traditional style within a contemporary setting [17]. From the late 19th century, the international reaction to threats towards heritage destruction has undergone significant refinement. The initial international collaboration efforts resulted in the promulgation of the 1972 Convention by UNESCO. The common approach of emphasising the importance of the historic environment has been the main concern of the international community. Subsequently, heritage values have been the main indicators employed in reconstruction debates [18].

Since then, the UNESCO mission has been amended, periodically, in response to the changing approaches to the concept of heritage, taking in both tangible and intangible, besides incorporating movable and digital. The mission is currently summarised as: "to contribute to the building of a culture of peace, the eradication of poverty, sustainable development and intercultural dialogue through education, the sciences, culture, communication and information" [19].

This statement has recently been converted into actions. Following the World Heritage Committee Decision at its 41st session in 2017, the Warsaw Recommendation on the Recovery and Reconstruction of Cultural Heritage was issued in May 2018 and approved by 200 international participants, including, inter alia, ICOMOS, ICCROM, the World Bank, UNISDR and UNESCO. Subsequently, the World Heritage Committee, at its 42nd session meeting held from 24th June-4th July 2018 welcomed the Warsaw Recommendation.

Indeed, the limitation of heritage policies in guiding a practical inclusive reconstruction project, after deliberate or accidental destruction, has been conceded at the Committee's 40th session in 2016: 
"Noting that the recent and wide-ranging deliberate destruction of world heritage properties as a result of armed conflict in Syria, Yemen, Libya, Iraq, Mali and Nigeria, and the devastating earthquakes in Nepal, have brought sharply into focus the issue of reconstruction in World Heritage properties; that several international meetings have taken place or are being planned on reconstruction; and that guidance within the Operational Guidelines is currently inadequate". [20] (p. 10)

The Warsaw Recommendation 2018 (WR), as a response to such debate, reflects on key antecedents, mainly the Nara Document on Authenticity of 1994, the Recommendation of the Historic Urban Landscape (HUL) of 2011, the Policy on the Integration of a Sustainable Development Perspective in the Processes of the World Heritage Convention (PISDP) of 2015, and the 2030 Agenda for Sustainable Development. Such reflection was explicated in its recommendations. For example, following the HUL perspectives, the WR perceives cultural heritage as living urban areas, and it explicitly integrates ICH in the reconstruction process [21]. The reflection on the 2015 PISDP and 2030 Agenda is made clear by putting forward the full engagement of local communities in the recovery and reconstruction process. Moreover, responding to the need for social justice, a rights-based approach that embraces the inclusion of 'refugees and internally displaced people' in such decisions, is a key SDG in post-conflict reconstruction procedures. The WR also envisages memorialization of destroyed sites through "interpretation or presentation that integrates a shared narrative of the traumatic events" [20] (p. 4). But surprisingly the WR provides neither clear definitions nor identifications of the inclusive set of values to be considered. Nor does it clarify which aspects of ICH should be integrated and when these should be implemented.

With similar motives, a collaboration between the UNESCO and the World Bank resulted in the publication of the position paper on Culture in City Reconstruction and Recovery in November 2018. This Paper "proposes a framework that mainstreams culture into post-crisis city reconstruction and recovery, integrating people-centered and place-based policies" [22] (p. 3). This is referred to as the CURE Framework. The Paper explains its position among other heritage documents by focusing on socio-cultural connections between the communities and their heritage environment. The position paper considers culture with all its components as one pillar of post-conflict reconciliation.

In a similar approach to the WR, the position paper acknowledges that the displacement of the local population will result in drastic changes to the social and economic fabric of a city. It also suggests that new cultural traditions might emerge as a result of the conflict and this might even replace the "cultural traditions of evacuated residents" [22] (p. 28). However, this is at odds with the position that considers inherited tradition as a driver for peace building.

This intention also runs against the recent approach by ICOMOS and UNESCO to encourage the nomination of heritage sites associated with post-disaster memories. This was underlined in the ICOMOS discussion paper entitled Evaluations of World Heritage Nominations Related to Sites Associated with Memories of Recent Conflicts, published in April 2018. This addresses the importance of linking the recommendations by the UNESCO 1972 Convention, the designation criteria according to OUV and commemoration as a criterion. The focus was on several sites that are nominated on the basis of criterion (vi) alone (relating to commemoration). An example is the Hiroshima Peace Memorial (Genbaku Dome, Japan), inscribed in 1978 [22]. Importantly, this discussion paper indicates associations between the sites of memory and outstanding universal value (OUV) and underlines the need to find out "whether and how sites associated with memories of recent conflicts might relate to the purpose and scope of the World Heritage Convention, and perhaps more widely to an understanding as to whether World Heritage inscription that fixes OUV at the time of inscription might sit uncomfortably with the wider complex and shifting dynamics of post-conflict reconciliation processes" [22] (p. 10).

A similar deliberation was also addressed in the study on Interpretation of Sites of Memory published in January 2018 - prepared in collaboration between UNESCO, the Republic of Korea and the International Coalition of Sites of Conscience (ICSC). The study is founded on work in previous 
key policies such as the HUL 2011, Nara 1994, Burra Charter 2013, ICH Convention 2003 and the Operational Guidelines 2015. The study extracts the definitions of several terms including memory, memorialisation and authenticity. Intangible cultural traditions and practices are designated as 'associative values' and include memories and spiritual connection between the associated community and heritage places. The study also underscores the inclusion of heritage in the UN Sustainable Development Goals (particularly point 11.4). This is clearly reflected in the definition of heritage adopted, such that "[heritage is] an important factor in the identity of communities and groups, and is included within the United Nations' Sustainable Development Goals 2030 ... Heritage sites are [also] seen as a major contribution to sustainable growth and the social and economic wellbeing of local communities, as well as to their sense of identity" [23] (p. 7).

Consequent to the review of recent published documents above, it is clear that innovative shifts in heritage polices have taken place recently. The aforementioned documents acknowledge several preceding key heritage policies that have been guiding the management of heritage globally for over 50 years. Selected earlier statements and definitions are also adopted to guide current reconstruction/reconciliation process. The emphasis on the integration of $\mathrm{ICH}$ and culture has gained more prominence. Additionally, the potential for re-nomination on the basis of post-trauma memory is a clear attempt to provide further support for devastated communities. The recognition of emerging intangible values and possibilities to integrate reconstruction with the 2030 Sustainable Development Agenda represent advanced approaches to post-conflict reconstruction.

However, potential contradictions with previous approaches to intangible tradition and practices might cause further confusion in the future. Moreover, ambiguity in the multiple values attributed to the heritage cities as embodying living heritage qualities, such as historic, educational, integrity and setting, might make inclusive reconciliation in the urban context more difficult.

This, then raises key questions that have not been fully addressed yet: How can the reconstruction process contribute to sustaining the remaining tangible and intangible heritage assets? What are the appropriate total values to be considered in post-conflict reconstruction/reconciliation? How can such reconstruction contribute to sustainable reconciliation?

\subsection{Reserach Objectives and Contributions}

In order to address the aforementioned questions, our research is therefore based on a rigorous and innovative review of the key heritage policies. Recalling Lostal's statement that "the test of a new proposal's viability will rest first and foremost on a firm understanding of what these treaties actually say" [14] (p. 108). There are four main elements, delivered over two papers. The first paper is the current article and it covers:

1. An interrogation of heritage policies, in which a rigorous content analysis (CA) is performed on 37 selected heritage documents. One aim is to arrive at an inclusive classification of post-conflict reconstruction and reconciliation for not just sustaining peace, but also for repositioning the heritage as a driver for sustainable development. The second aim is to extract heritage values that have been linked to both tangible and intangible aspects of heritage, besides understanding their association with the pillars of sustainability;

2. Based on the results of this analysis, key principles are recommended for integration with international policy documents in order to fill in the gaps identified. While, the second paper deals with:

3. A framework for leading the reconciliation process. This is established based on the results of the CA reviewed in the first paper.

4. The framework is tested against two case studies in Syria: Old Damascus and Old Aleppo.

This article is written to contribute to solving an actual problem facing decision makers on post-conflict reconstruction and sustainable reconciliation. The proposed framework is a collective 
interpretation of previous policies and guidance, and is in line with the 1972 World Heritage Convention that integrates SDGs in reconstruction.

\section{Methodology}

The methodology adopted in this paper, is based on a rigorous review of cultural heritage policy documents. The selection of each document was based upon meeting one or more criterion, from each set of criteria below, in relation to subject, application level, and authoritative organisation as follows:

Subject-documents that present guidance for:

- $\quad$ safeguarding a heritage urban area, town and/or city;

- safeguarding particular values;

- post-conflict reconstruction and/or reconciliation;

- heritage and sustainable development.

Application level—documents, which are applicable at:

- an international level.

- the Middle East and North Africa level.

Authoritative Organisations-documents authorised by:

- UNESCO and ICOMOS.

- $\quad$ other well-established international organizations.

To maintain an international overview, we focused on UNESCO and ICOMOS policies as the sample for analysis. However, we would like to acknowledge that a wide range of documents in relation to reconstruction and sustainability was issued by other organisations, such as the Council of Europe and the Organisation of World Heritage Cities. However, these are not included in our analysis. The sample for analysis covers 37 documents that best meet our selection criteria. The documents are listed chronologically starting from the UNESCO Convention of 1972. shown in Table 1.

Consequently, this study employed a content analysis methodological approach. This Analysis involves the classification of a set of texts according to coding roles that are derived from previous knowledge and data [24,25].

Table 1. Cultural heritage policy documents analysed.

\begin{tabular}{clcc}
\hline \multicolumn{1}{c}{ Cultural Heritage Policy Documents } & Organisation & Date \\
\hline 1 & $\begin{array}{l}\text { Convention concerning the protection of the world cultural \& } \\
\text { natural heritage }\end{array}$ & UNESCO & 1972 \\
\hline 2 & Seminar on the integration of modern architecture in old surroundings & ICOMOS & 1974 \\
\hline 3 & Declaration of Dresden: reconstruction of monuments destroyed by war & ICOMOS & 1982 \\
\hline 4 & The Washington charter (conservation of historic towns \& urban areas) & ICOMOS & 1987 \\
\hline 5 & Recommendation on the safeguarding of traditional culture and folklore & UNESCO & 1989 \\
\hline 6 & The Fez charter: charter of the Organisation of World Heritage Cities & OWHC & 1993 \\
\hline 7 & The Nara document on authenticity & ICOMOS & 1994 \\
\hline 8 & $\begin{array}{l}\text { Declaration of San Antonio: authenticity in the conservation and } \\
\text { management of the cultural heritage }\end{array}$ & ICOMOS & 1996 \\
\hline 9 & $\begin{array}{l}\text { Management guidelines for world cultural heritage sites } \\
\text { Second protocol to the Hague convention for the protection of cultural } \\
\text { properties in the event of armed conflict }\end{array}$ & ICCROM et. al. & 1998 \\
\hline 11 & $\begin{array}{l}\text { The Burra charter for the conservation of places of cultural significance } \\
\text { The Riga charter on authenticity \& historical reconstruction in relationship }\end{array}$ & ICOROM \& & 1999 \\
\hline 12 & $\begin{array}{l}\text { Th cultural heritage } \\
\text { UNESCO }\end{array}$ & 1999 \\
\hline
\end{tabular}


Table 1. Cont.

\begin{tabular}{|c|c|c|c|}
\hline \multicolumn{2}{|r|}{ Cultural Heritage Policy Documents } & Organisation & Date \\
\hline 13 & $\begin{array}{l}\text { The charter of Krakow: principles for conservation and restoration of } \\
\text { built heritage }\end{array}$ & Bureau Krakow & 2000 \\
\hline 14 & $\begin{array}{l}\text { Istanbul declaration: intangible cultural heritage, mirror of } \\
\text { cultural diversity }\end{array}$ & UNESCO & 2003 \\
\hline 15 & $\begin{array}{l}\text { Charter-Principles for the analysis, conservation \& structural restoration } \\
\text { of architectural heritage }\end{array}$ & ICOMOS & 2003 \\
\hline 16 & Convention for the safeguarding of intangible cultural heritage & UNESCO & 2003 \\
\hline 17 & Declaration concerning the intentional destruction of cultural heritage & UNESCO & 2005 \\
\hline 18 & Vienna memorandum on world heritage \& contemporary architecture & UNESCO & 2005 \\
\hline 19 & $\begin{array}{l}\mathrm{XI} \text { 'AN Declaration on the conservation of the setting of heritage structures, } \\
\text { sites \& areas }\end{array}$ & ICOMOS & 2005 \\
\hline 20 & $\begin{array}{l}\text { The INTBAU Venice declaration (on the conservation of monuments and } \\
\text { sites in the 21st century) }\end{array}$ & INTBAU & 2007 \\
\hline 21 & The interpretation \& presentation of cultural heritage sites & ICOMOS & 2008 \\
\hline 22 & Québec declaration on the preservation of the spirit of place & ICOMOS & 2008 \\
\hline 23 & $\begin{array}{l}\text { Bethlehem charter: the safeguarding of Palestinian historic towns and } \\
\text { urban landscape }\end{array}$ & UNESCO & 2008 \\
\hline 24 & $\begin{array}{l}\text { Kit of the convention for the safeguarding of the intangible cultural } \\
\text { heritage (ICH and sustainable development) }\end{array}$ & UNESCO & 2009 \\
\hline 25 & $\begin{array}{l}\text { Compendium II - the conservation of cultural heritage properties on the } \\
\text { world heritage on Danger List }\end{array}$ & ICOMOS & 2009 \\
\hline 26 & $\begin{array}{l}\text { New Zealand charter for the conservation of places of cultural } \\
\text { heritage value }\end{array}$ & ICOMOS & 2010 \\
\hline 27 & Valletta principles - historic cities, towns \& urban areas & ICOMOS & 2011 \\
\hline 28 & $\begin{array}{l}\text { Guidance on heritage impact assessments for cultural world } \\
\text { heritage properties }\end{array}$ & ICOMOS & 2011 \\
\hline 29 & Paris declaration on heritage as a driver of development & UNESCO & 2011 \\
\hline 30 & Recommendation on the historic urban landscape & UNESCO & 2011 \\
\hline 31 & $\begin{array}{l}\text { Hangzhou declaration: placing culture at the heart of sustainable } \\
\text { development }\end{array}$ & UNESCO & 2013 \\
\hline 32 & Burra charter for the conservation of places of cultural significance & ICOMOS & 2013 \\
\hline 33 & $\begin{array}{l}\text { Integration of a sustainable development perspective into the processes of } \\
\text { the world heritage convention }\end{array}$ & UNESCO & 2015 \\
\hline 34 & $\begin{array}{l}\text { Operational guidelines for the implementation of the world heritage } \\
\text { convention }\end{array}$ & UNESCO & 2017 \\
\hline 35 & $\begin{array}{l}\text { Guidance on post trauma recovery and reconstruction for world heritage } \\
\text { cultural properties }\end{array}$ & ICOMOS & 2017 \\
\hline 36 & $\begin{array}{l}\text { Warsaw recommendation on recovery \& reconstruction of } \\
\text { cultural heritage }\end{array}$ & UNESCO & 2018 \\
\hline 37 & Position paper: culture in city reconstruction and recovery & $\begin{array}{l}\text { UNESCO/World } \\
\text { Bank }\end{array}$ & 2018 \\
\hline
\end{tabular}

\section{Content Analysis of International Heritage Policy Documents}

The analysis procedure started by collecting all of the selected documents in PDF format. Subsequently, the analysis employed a collective content analysis utilising simple searches in the PDF files. There was no use of a more advanced software, as the terms and phrases being searched for were complex and dependent on their contextual use. The phrases or terms were then identified 
and grouped manually in a spreadsheet to sort and classify our understanding of their contextual use and relationships. Despite the fact that the manual process applied was time consuming, it provided a comprehensive outcome, as some complex aspects would have been missed using an automated technique [25]. The manual search involved extracting useful information in relation to:

(a) advocacy for post-conflict reconstruction and reconciliation;

(b) heritage values.

The initial analysis adopts keywords that are based on pre-defined set of terms including values, reconstruction, reconciliation and sustainability. These were based on a review of previous similar studies, (see $[3,26,27])$. During the analysis conducted for this paper, three overlapping steps were followed:

Step 1. Establish the themes and variables: The key terms under inspection were values or significances; besides tracing specific idioms such as authenticity, integrity, sustainable, social and cultural. Key definitions of terms such as restoration, reconstruction, reconciliation and sustainability, were also extracted.

Step 2. Decide on terms within the scope: The actual frequency of the terms reviewed were not considered in our analysis. However, this might be developed in future research. Generalised terms and phrases were used for some values, thus both exact and close-match terms were extracted. An example is the extraction of 'historic value', where terms such as 'historic significance' or 'age value' were subsumed.

Step 3. Analyse the results. The non-relevant information in the documents analysed were filtered out before processing of the content in detail. The definitions extracted for reconstruction, reconciliation and for each value were grouped and classified under headings of both tangible and intangible features of the historic built environment, as well as their relation to sustainability dimensions and other values. The aim was to facilitate a more effective translation of heritage documentation into practical actions in real-world scenarios.

It is important to acknowledge that despite the production of a database that allows for a clearer understanding of the concept being analysed, the content analysis strategy is a time consuming methodology [24,25].

\section{Results}

\subsection{Reconstruction, Reconciliation and Sustainability}

Appropriate reconstruction that follows precise documentation and indisputable understanding of the material heritage was generally advocated by about 17 documents in our study. Explicit definitions of reconstruction were presented in only 10 documents. Interestingly, the majority of these followed the legacy of the Venice Charter 1964 by considering that the reconstruction of entire parts "in the style of the building" should be avoided. Reconstruction was also distinguished from restoration, by the introduction of new material to replace material that has been lost and by reflecting contemporary architecture.

The particular case of reconstruction after destruction caused by natural or man-made disasters was discussed in 6 documents; Declaration of Dresden 1982, Krakow Charter 2000, Kit of the Convention for the Safeguarding of the ICH 2009, Guidance on Post Trauma Recovery 2017, Warsaw Recommendation 2018, and Culture in City Reconstruction and Recovery 2018.

In order to simplify our understanding of post-disaster reconstruction and reconciliation within the 6 documents listed above, Table 2 was created. The extracted definitions are analysed in terms of $\mathrm{ICH}, \mathrm{TCH}$ and sustainable development. The definitions are abridged in the respective column of Table 2. 
Table 2. Post-disaster reconstruction in heritage policy documents.

\begin{tabular}{|c|c|c|c|}
\hline \multirow{2}{*}{ Documents } & \multicolumn{3}{|c|}{ Post-Disaster Reconstruction } \\
\hline & ICH Elements and Values & TCH Elements and Values & Sustainability \\
\hline Dresden 1982 & $\begin{array}{l}\text { Spiritual, symbolic, pride, } \\
\text { history, social progress, } \\
\text { artistry, beauty, } \\
\text { craftsmanship }\end{array}$ & $\begin{array}{l}\text { Character of towns, natural } \\
\text { setting, authenticity }\end{array}$ & New cultural dimensions \\
\hline Krakow 2000 & $\begin{array}{l}\text { Social and cultural motives, } \\
\text { community's identity }\end{array}$ & $\begin{array}{l}\text { Architectural significance, } \\
\text { morphology, surrounding } \\
\text { landscape, technological, } \\
\text { spatial, decorative } \\
\text { characteristic, authenticity } \\
\text { and integrity }\end{array}$ & $\begin{array}{l}\text { Involve all sectors of the } \\
\text { population, link heritage } \\
\text { issues with social and } \\
\text { economic aspects }\end{array}$ \\
\hline ICH Kit 2009 & All ICH domains & $\begin{array}{l}\text { Shared spaces and natural } \\
\text { resources }\end{array}$ & $\begin{array}{c}\text { Association between ICH and } \\
17 \text { Sustainable Development } \\
\text { Goals }\end{array}$ \\
\hline $\begin{array}{l}\text { Guidance on } \\
\text { Post Trauma } \\
\quad 2017\end{array}$ & $\begin{array}{l}\text { OUV (all ICH), formal and } \\
\text { informal structures of } \\
\text { urban societies, authenticity }\end{array}$ & OUV (authenticity criteria) & $\begin{array}{l}\text { Improve the quality of life, } \\
\text { social and economic fabric }\end{array}$ \\
\hline $\begin{array}{c}\text { Warsaw } \\
\text { Recommendation } \\
2018\end{array}$ & $\begin{array}{c}\text { Listing criteria (OUV, } \\
\text { authenticity, integrity), } \\
\text { values by communities, } \\
\text { memory, remembrance, } \\
\text { education, tourist } \\
\text { information, dignity, } \\
\text { identity }\end{array}$ & OUV, Authenticity, integrity & $\begin{array}{l}\text { Achieving the } 2030 \text { agenda for } \\
\text { sustainable development, } \\
\text { cultural diversity, new values } \\
\text { by community, considering } \\
\text { displaced people }\end{array}$ \\
\hline $\begin{array}{l}\text { Culture in City } \\
\text { Reconstruction } \\
2018\end{array}$ & $\begin{array}{l}\text { The city as a "cultural } \\
\text { construct", where (social } \\
\text { fabric and cultural } \\
\text { expressions are linked to } \\
\text { the built structures and } \\
\text { open spaces), }\end{array}$ & $\begin{array}{l}\text { Landmarks and places of } \\
\text { cultural significance to local } \\
\text { communities }\end{array}$ & $\begin{array}{l}\text { Social, cultural and economic } \\
\text { development, engaging } \\
\text { communities and local } \\
\text { governments, finance models, } \\
\text { balance between historic } \\
\text { character of the city and the } \\
\text { needs of the communities }\end{array}$ \\
\hline
\end{tabular}

Table 2 exemplifies an evolution, across documents, of the guidance moving more clearly towards 'sustainable reconstruction' and eventual 'reconciliation'. Three important paradigm shifts in guidance were recognised. First the importance of considering the sustainability dimensions (economic, social and environmental) during the reconstruction of the historic urban area was underscored. Second, understanding the heritage as a "living urban context", or "a historic urban landscape", as formalised in 2011 by the Recommendation on the Historic Urban Landscape (HUL), was emphasised, albeit before this document was officially issued. Third, a clear indication of reconstruction in the light of the heritage designation criteria for the purpose of relisting was formulated in Warsaw Recommendation 2018.

It is also revealed that the Declaration of Dresden identified the role of the ICH in the reconstruction process as early as 1982. As a consequence, the term 'new cultural dimensions' was then recognised. These were later underlined by Warsaw Recommendation 2018 as 'new values'. However, despite the recognition of $\mathrm{TCH}$ and ICH elements and values in these documents, each document presented these in its particular way.

The Guidance on Post Trauma 2017 and Warsaw Recommendation 2018 documents are certainly revolutionary policies. They both respond to the current challenges of post-conflict reconstruction and reconciliation. They have shifted the paradigm of guidance into a new level. The earlier defines seven categories of possible reconstruction in relation to tangible and intangible attributes of OUV. The emphasis on the sustainability dimensions in reconstruction was clearly articulated by the Warsaw Recommendation 2018. The 2017 document accentuates ICH, only in relation to OUV, while the latter emphasises the values recognised by the local communities including displaced people, but with no clear definition of these values. 
The Kit 2009 Document demonstrates the links between all domains of ICH and the total 17 Sustainable Development Goals (SDGs), it also highlights the importance of 'local social practices of dialogue' and traditional activities in re-creating peace after conflict. This document has initiated the use of the term 'reconciliation' when denoting both tangible and intangible reconstruction after conflict. It asserts that throughout the post-conflict reconstruction process, safeguarding traditional activities with shared memories would bring together local communities with their diverse cultural backgrounds, which would stimulate reconciliation via "intercultural dialogue". Accordingly, this would help establish a "sustainable strategy to re-establish peace and safety within a society" [28] (p. 14).

The links between post-conflict reconstruction and sustainability was also mentioned in the Culture in City Reconstruction 2018 document, but only in relation to Goal 11 "to make cities and human settlements inclusive, safe, resilient, and sustainable" [22] (p. 16). This goal identifies heritage actions as essential catalysts for promoting sustainable development (Target 11.4). The document states that "intangible cultural heritage represents a source of resilience and knowledge for addressing key challenges including poverty and disasters. Intercultural dialogue and respect for cultural diversity are powerful tools for reconciliation and the creation of peaceful societies" [22] (p. 16).

In addition to the aforementioned documents, the role of heritage in peace times as a driver for sustainable developments was presented in four documents reviewed in our study. These are the Paris Declaration 2011, Hangzhou Declaration 2013, Integration of a Sustainable Development Perspective into the World Heritage Convention 2015, and very concisely in the Operational Guidelines (OGs) 2017. The Paris Declaration summarises the set of values that are likely to be associated with heritage; these are identity, historical, cultural and social memory, conserved through the authenticity, integrity and 'sense of place' [29] (p. 2). It also highlights the particular role of the intangible attributes of heritage in promoting understanding between communities" [29] (p. 2).

In a similar vein, the Hangzhou Declaration 2013 underscores the role of heritage in sustainable development and calls for a more practical policies "to secure the protection and promotion of this heritage and of its inherited systems of values and cultural expressions ..., while giving it a central role in the life of societies" [30] (p. 5). The Integration of a Sustainable Development Perspective 2015 argues that the 1972 Convention has, already, incorporated the environmental, social and economic dimensions of sustainable development within its recommendation. Further consideration of the economic dimension, peace building and gender equality was also advocated, mainly for State Parties to consider. The OGs highlighted the role of the natural and cultural heritage within the sustainable development strategy" [31] (p. 10).

Therefore, we can argue that from the heritage policies' perspective, sustainable post conflict reconciliation (SPCR) aims to making the heritage areas affected "inclusive, safe, resilient and sustainable", SDG11. In doing so, it proposes an operative and sustainable approach to restore both built environment and social fabric for sustainable peace, prosperity and security within the local society. The reconstruction of material heritage can take different forms and approaches depending on the values prioritised for the communities. These are detailed in the ICOMOS Guidance on Post Trauma 2017. At the same time, all types of intangible heritage and intangible values associated with the local communities' interest and benefits should be considered. The ICH Kit 2009 and Culture in City Reconstruction 2018 are key guidance.

Accordingly, in the light of our analysis, sustainable post-conflict reconciliation should respect:

- the urban heritage context in terms of the character of towns, natural settings and resources, urban morphology, shared spaces and significant cultural landmarks, and places, which are highly important to local communities;

- tangible elements of heritage, particularly, architectural significance, technological, spatial and decorative characteristic, besides respecting the designation values of OUV, authenticity and integrity; and 
- all ICH domains associated with the tangible heritage in question, besides safeguarding the intangible aspects of spiritual, symbolic, pride, history, social, cultural, aesthetic and identity values. ICH aspects of the designation values should also be considered.

- From Section 3.1 in this paper, it was clear that associating sites with memory in post-conflict era has been recently emphasised, therefore, this is included in our proposed definition of reconciliation.

These decisions should be taken in line with relative local and international heritage guidance, as well as assuring full involvement of local authorities and all local interest communities. New values or cultural dimensions emerged should also be considered.

Despite the lack of complete consensus among the documents in terms of definitions of post-conflict reconstruction/reconciliation actions, our content analysis demonstrates that the road to post-conflict reconstruction, reconciliation and sustainable development can be led by broadly accepted core of tangible and intangible cultural heritage values and significances. Our study also reveals particular areas where clarifications are needed. These are related to heritage values and the tangible and intangible elements of heritage associated with these values, as well as identifying more clearly how these contribute to sustainable development.

An important original aspect of the cultural heritage policy analysis described here, is the articulation of how sustainable development has been linked to heritage in peace and in post conflict situations. Additionally, the collected set of clarifications in relation to effective reconstruction enables a comprehensive understanding of 'sustainable post-conflict reconciliation' in a cultural heritage context. As such, these can be further developed to inform the promulgation of an inclusive heritage policy, which is urgently needed.

\subsection{Heritage Values}

During the content analysis (CA) review, 10 main values were identified. These are: cultural, social, historical (including political), identity, intangible (including spiritual), authenticity, integrity, Outstanding Universal Value (OUV), aesthetic, and economic. No document contains all of these. Equally, while some values were found to be frequently cited in the majority of the documents-in particular social, cultural and historical—the reference to other values was limited, notably integrity and aesthetic values.

The definitions of the 10 values are presented below with reference to the appropriate documents. Additionally, the tangible and intangible aspects associated with each definition provided were coded separately. Any references to sustainability dimensions were also identified-these are signified by italics in Table 3. Links with citations of other values were also made bold; see Table 3.

Table 3. Definitions of 10 key heritage values extracted from heritage policy documents.

\begin{tabular}{|c|c|}
\hline Documents & Definitions of Cultural Value \\
\hline [32] & $\begin{array}{l}\text { This source notes that cultural values depend on interpretations that reflect the time. They are classified as: } \\
\text { (a) Identity values (see definition) } \\
\text { (b) Relative artistic or technical value is related to "the design of the heritage resource, and the } \\
\text { significance of its technical, structural and functional concept and workmanship". } \\
\text { (c) Rarity value: "style, builder, period, and region". (Might reinforce the outstanding universal value). }\end{array}$ \\
\hline [33] & $\begin{array}{l}\text { Here the meaning is retaining "aesthetic, archaeological, architectural, } \\
\text { commemorative, functional, historical, landscape, monumental, scientific, } \\
\text { social, spiritual, symbolic, technological, and traditional values". }\end{array}$ \\
\hline [34] & $\begin{array}{l}\text { Here the term covers "aesthetic, historic, scientific, social or spiritual value for past, present or future } \\
\text { generations". It is embodied "the place itself, its fabric, setting, use, associations, meanings, records, } \\
\text { related places and related objects". } \\
\text {--------- } \\
\text { "pultural value refers to the beliefs of a cultural group, such as } \\
\text { "political, religious, spiritual and moral beliefs". }\end{array}$ \\
\hline
\end{tabular}


Table 3. Cont

\begin{tabular}{|c|c|}
\hline Documents & Definitions of Cultural Value \\
\hline Documents & Definitions of social value \\
\hline [33] & $\begin{array}{l}\text { This source defines social value in relation to "traditional social activities and to compatible present-day use". } \\
\text { This includes "contemporary social interaction in the community, and establishes social and cultural } \\
\text { identity". }\end{array}$ \\
\hline Documents & Definitions of historic value \\
\hline [35] & $\begin{array}{l}\text { This source notes that "the history of a site should not be manipulated to enhance the dominant values of } \\
\text { certain groups over those of others". }\end{array}$ \\
\hline [33] & $\begin{array}{l}\text { This document says "Political value is related to a specific event in the history of the heritage resource } \\
\text { with respect to its region or country. The present-day significance could be influenced by these events } \\
\text { insofar as they coincide with the intention of contemporary political priorities". }\end{array}$ \\
\hline [36] & $\begin{array}{l}\text { "A place may have historic value because it has influenced, or has been influenced by, an } \\
\text { historic figure, event, phase or activity". }\end{array}$ \\
\hline Documents & Definitions of identity value \\
\hline [33] & $\begin{array}{l}\text { This source notes the importance of the connection between the local population and the site, in terms of } \\
\text { "whose identity the site reflects". } \\
\text { Cultural identity (our languages, our societal structures, our economic means, and our spiritual beliefs) is } \\
\text { at the core of the national life. } \\
\text { Here Identity values relate to the "emotional ties of society to specific object or sites"; } \\
\text { (age, tradition, continuity, memorial, legendary; wonder, sentiment, spiritual, religious; and } \\
\text { symbolic, political, patriotic, and nationalistic). }\end{array}$ \\
\hline [37] & $\begin{array}{l}\text { In this source, Identity refers "to both present values generated in the sphere of a community and past } \\
\text { values identified in its authenticity". }\end{array}$ \\
\hline [38] & $\begin{array}{l}\text { This document notes that "townscapes, roofscapes, main visual axes, building plots and types are integral } \\
\text { parts of the identity of the historic urban landscape". }\end{array}$ \\
\hline Documents & Definitions of authenticity value \\
\hline [32] & $\begin{array}{l}\text { This document suggests that properties would meet the conditions of authenticity if their cultural values } \\
\text { are expressed through: "form and design; materials and substance; use and function; } \\
\text { traditions, techniques and management systems; location and setting; } \\
\text { language, and other forms of intangible heritage; spirit and feeling". } \\
\text { Thus "artistic, historic, social, and scientific dimensions of the cultural heritage would be elaborated". }\end{array}$ \\
\hline [33] & $\begin{array}{l}\text { This source refers to the "true value; whether the resource remains in the condition of its creation and } \\
\text { reflects all its significant history". } \\
\text { Context: corresponding to the original or other periods of significance; and enhancing or diminishing the } \\
\text { significance Use and function, the traditional patterns of use that have characterized the site". }\end{array}$ \\
\hline [38] & $\begin{array}{l}\text { This source says that "authenticity means the sum of substantial, historically ascertained characteristics: } \\
\text { from the original up to the current state, as an outcome of the various transformations that have occurred } \\
\text { over time". }\end{array}$ \\
\hline Documents & Definitions of OUV value \\
\hline [32] & $\begin{array}{l}\text { This document states that OUV means the cultural and/or natural significance which is so exceptional as to } \\
\text { transcend national boundaries and to be of common importance for present and future generations of all } \\
\text { humanity. Criteria for the assessment of OUV, please see all criteria (i) to (x) [33]. }\end{array}$ \\
\hline [39] & $\begin{array}{l}\text { This source says that "OUV may include intangible factors, such as } \\
\text { socioeconomic structures, the rituals, narratives, skills and livelihood } \\
\text { activities of resident populations, and inhabitants' relationships with history and the past. OUV may be } \\
\text { integral to the ongoing place-making activities of individuals and communities". }\end{array}$ \\
\hline [40] & $\begin{array}{l}\text { This document considered that "large-scale projects could have the potential to impact adversely on the } \\
\text { appearance, skyline, key views and other different attributes that contribute to OUV". }\end{array}$ \\
\hline Documents & Definitions of integrity value \\
\hline [41] & $\begin{array}{l}\text { Integrity, here "refers to whether the site is fragmented; how much is missing, and what are the } \\
\text { recent additions". }\end{array}$ \\
\hline
\end{tabular}


Table 3. Cont.

\begin{tabular}{|c|c|}
\hline Documents & Definitions of Cultural Value \\
\hline [33] & $\begin{array}{l}\text { This sources says that "Integrity refers to the material completeness and sound condition of an object or } \\
\text { site, whereas 'historical integrity' relates to the current form of heritage resource as a result of growth and } \\
\text { changes over time. It is related to } \\
\text { archaeological sites, materials, workmanship, setting and relationship to the setting". }\end{array}$ \\
\hline [32] & $\begin{array}{l}\text { This document says that "Integrity is a measure to which the property: } \\
\text { (a) includes all elements necessary to express its outstanding universal value; } \\
\text { (b) is of adequate size to ensure the complete representation of the features and processes which convey the } \\
\text { property's significance; } \\
\text { (c) suffers from adverse effects of development and/or neglect". }\end{array}$ \\
\hline Documents & Definitions of economic value \\
\hline \multirow[t]{2}{*}{ [33] } & $\begin{array}{l}\text { This source says "Economic value may be a value generated by the heritage resource or by } \\
\text { conservation action." }\end{array}$ \\
\hline & "It has four potential sources of revenue: tourism, commerce, use and amenities". \\
\hline [42] & $\begin{array}{l}\text { Economic value here is "the cultural value expressed in economic terms, including use (market) values } \\
\text { and non-use values. Non-use values are estimated by revealed-preferences survey techniques, providing } \\
\text { willingness-to-pay estimates for local residents or visitors". }\end{array}$ \\
\hline Documents & Definitions of intangible value/heritage \\
\hline [43] & $\begin{array}{l}\text { This document notes that "Folklore reflects cultural and social identity. Its forms are } \\
\text { language, literature, music, dance, games, mythology, rituals, customs, } \\
\text { handicrafts, architecture and other arts". }\end{array}$ \\
\hline [42] & $\begin{array}{l}\text { This source notes that "Spiritual meaning of heritage is manifested through customs and traditions, } \\
\text { settlement patterns, land use practices, and religious beliefs". }\end{array}$ \\
\hline$[29,44]$ & $\begin{array}{l}\text { In these sources ICH means "the practices, representations, expressions, knowledge, skills-as well as the } \\
\text { instruments, objects, artefacts and cultural spaces associated therewith-that communities, groups and } \\
\text { individuals recognize as part of their cultural heritage. This ICH, transmitted from generation to generation, is } \\
\text { constantly recreated by communities and groups in response to their environment, their } \\
\text { interaction with nature and their history, and provides them with a sense of identity and continuity, thus } \\
\text { promoting respect for cultural diversity and human creativity". } \\
\text { The ICH is manifested in the following domains: } \\
\text { "Oral traditions and expressions, performing arts, Social practices, rituals and festive events, } \\
\text { Knowledge and practices concerning nature and the universe, traditional craftsmanship". }\end{array}$ \\
\hline [34] & $\begin{array}{l}\text { Here, Intangible value means the "abstract cultural heritage value of the meanings or associations of a } \\
\text { place, including commemorative, historical, social, spiritual, symbolic, or traditional values". }\end{array}$ \\
\hline [45] & $\begin{array}{l}\text { This describes Spirit of place is "the tangible (buildings, sites, landscapes, routes, objects) and the } \\
\text { intangible elements } \\
\text { (memories, narratives, written documents, rituals, festivals, traditional knowledge, values, } \\
\text { textures, colours, odours, etc.), that give meaning, value, emotion and mystery to place". }\end{array}$ \\
\hline Documents & Definitions of aesthetic value \\
\hline [37] & $\begin{array}{l}\text { This includes "the form, scale, colour, texture and material of the fabric; the smells and sounds associated } \\
\text { with the place and its use. } \\
\text { Aspects of the visual setting may include use, bulk, form, scale, character, colour, texture and materials". }\end{array}$ \\
\hline
\end{tabular}

It is important to note that additional values were also found, but these were infrequently cited in the documents. Examples are educational value, which was linked to promotion of cultural tourism and intrinsic value that was defined in line with aspects similar to integrity value (see [33]).

The definitions of values provided by the documents selected in our study, Table 3, reveal that most of these had reference to both tangible and intangible aspects and attributes of cultural heritage. Specific issues can be gleaned from the interrogations above. For example, cultural values were often defined in an inclusive way to embrace all other values. But, this might lead to confusion in practice, due to the lack of specific direction.

Also evident were: 
- a lack of distinction between intangible values that give meaning to places,

- clarity on ICH elements that are associated with places, and

- the nature of evidence of authenticity and OUV for World Heritage properties.

Additionally, some definitions do not reflect the commonly used meaning of certain values. A clear example is the historic value, in which no references were found in relation to architectural heritage, such as historic features of a monument. These issues of contradictions would need discussion in future research.

It is intended that the analysis above can have practical importance in cases of reconciliation and sustainable reconstruction after conflict at the international level, as all the revisited documents in our study have been recommended for the management of the UNESCO World Heritage Sites. The extracted list of heritage values above can be used by policymakers to enhance current and future policies for sustainable post-conflict reconciliation; and to aid consistency in those documents.

These international policies would in turn inform the Syrian law and assist in addressing the current challenges facing post-conflict reconciliation.

However, despite some inconsistency, the principles and guidance advocated in these particular documents, in addition to the comprehensive understandings of 'sustainable post-conflict reconciliation' and 'heritage values' extracted from the total documents analysed in our study, form the core of the action framework that arises from this study.

\section{Discussion}

The values linked to sustainable reconciliation and heritage, extracted above are useful to be integrated in heritage policies. However, we noted above some inconsistency or ambiguity across documents in certain terms and phrases. This problem can be exacerbated, when these terms are translated into different languages, Arabic in our case.

As the ultimate aim of our research is to arrive at a pragmatic and operable framework for sustainable post-conflict reconciliation, a further step was implemented in our analysis. This step embraces the creation of an index and the process of synthesising the extracted information into practical reference tables. This process brings with it the challenge of 'personal interpretation' of terms and concepts. Therefore, a consistent, objective content analysis, following the steps highlighted earlier, was applied to the extracted results presented above. Accordingly, the definitions extracted for each value were classified under headings of both tangible and intangible elements of the historic built environment, in line with the 2011 HUL recommendations. In order to arrive at an additional layer of synthesis in this directory, we grouped the tangible elements in terms of their urban and singular/architectural association. Additionally, we differentiate between the intangible heritage domains and the intangible values of heritage. Finally, these elements were associated with the key sustainability dimensions. The outcome is presented in Table 4 .

The relation between key concepts, established in this article, particularly in Tables 2 and 4, indicates that in order to arrive at a comprehensive sustainable reconciliation, an inclusive set of heritage values should be considered. These are associated with both tangible and intangible aspects of the cultural heritage asset in question. The level of destruction will also be influential. For example, if the main value is related to the architectural and authentic style of heritage in a moderately destroyed heritage context, and the reconstruction aims for possible re-designation, then authenticity, integrity and OUV should logically be considered first. In another scenario and with a similar aim of re-designation, but with an extensive level of destruction, ensuring the continuity of relevant intangible heritage qualities becomes a more dominating determinant for achieving the sustainability. Such consequences, for application in practical contexts will be explored in the second paper. 
Table 4. Index of heritage values and associated tangible and intangible elements of cultural heritage.

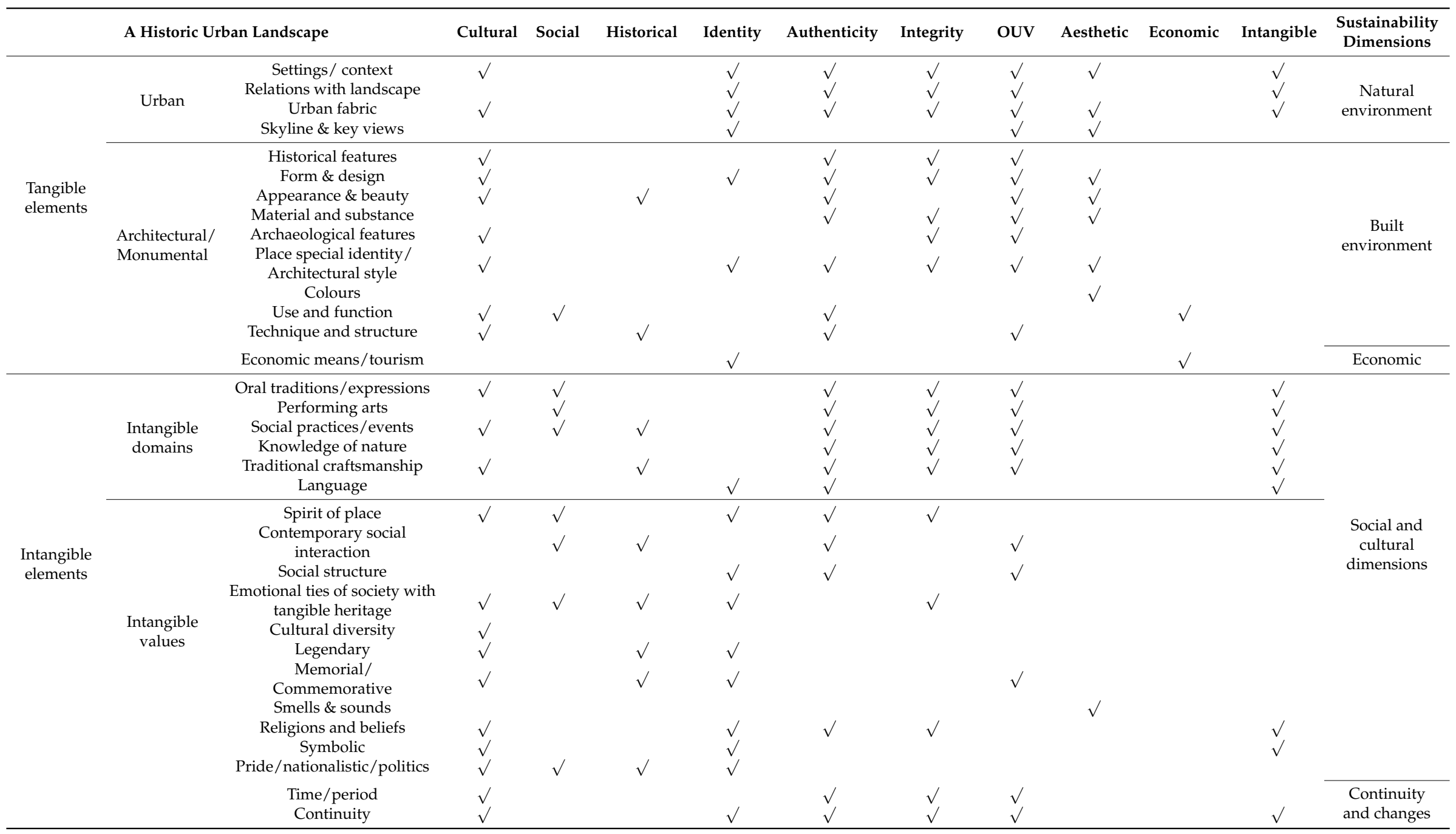


Table 4 also offers a detailed insight into the contextual gaps in the definitions of heritage values proposed by the 37 policies analysed. For example, the historical value was associated with a number of intangible elements, including domains and values. However, it was only associated with two tangible elements in terms of architectural and monumental aspects of heritage. These are appearance \& beauty, and technique \& structure. In practice, the historical value might have further associations with tangible elements, such as the urban fabric and the associated historical features.

Equally, safeguarding some elements throughout the reconciliation process might have strong connections with particular values, which were not addressed by the heritage policies. For example, from Table 4, it is clear that the archaeological features were proved to be contextualised along with the values of cultural, integrity and OUV. Albeit, in practice, archaeological features have a robust connection with social, historical and identity values during the course of the actual reconciliation process. This relationship has not been identified by the documents according to our content analysis. More importantly, despite mapping the associations between the heritage values, elements and sustainability dimensions in Table 4 , achieving an inclusive sustainable reconciliation requires further construction relative connotations, which should be considered in future documentations.

Therefore, we can argue that the content analysis methodology seems to offer an exclusive opportunity to explore and develop the definitions of heritage values in terms of their associations with all heritage elements, and accordingly arrive at a practical sustainable and inclusive reconstruction. These aspects will be explored further in the subsequent paper of our research, when these conceptual extractions will be applied to the heritage context of Old Aleppo and Old Damascus.

\section{Conclusions}

The intention of our research, in these two papers, is to provide a basis for a better-founded heritage-led sustainable post-conflict reconciliation. In this first part, a response to the diverse nature and foci of heritage guidance documents is formulated. This is underpinned by a comprehensive content analysis (CA) strategy that interrogated the text of 37 leading heritage documents. This paper then outlined how the analysis can help facilitate a particular categorisation to simplify the understanding of 10 key heritage values and their associated tangible and intangible heritage elements. This was then integrated with previously extracted interpretations of reconstruction/reconciliation from the perspectives of the inspected documents. Our aim is to make a contribution to the ongoing preparation of guidance at both national and international levels. In addition to the extractions of values and contextualising a possible pathway to a sustainable reconciliation that could be useful in post-conflict context, the strategy developed in this paper identified three key international policies that could usefully inform the current heritage law in Syria.

The first aim of this paper 'to define an appropriate style for reconstruction that is based on sustaining the heritage values and maintaining the continuity of the role of heritage in the life of its community' was addressed. Table 2 summarises post-conflict reconciliation terms as applied by 6 documents. Three paradigm shifts in policies were recognized: Firstly, there is the emphasis on the association with the sustainability dimensions during the reconstruction, understanding heritage as "a historic urban landscape", and the emphasis on heritage designation criteria through the reconciliation procedure for relisting. The analysis also suggests that traditional, contemporary and 'new' intangible socio-cultural dimensions ought to be recognised in such process. Accordingly, an answer to the first question raised in our introduction "how can the reconstruction process contribute to sustaining the remaining tangible and intangible heritage assets?" is provided. This is based on establishing a reconstruction procedure that respects first the urban heritage context including the character of town, natural settings, urban morphology, shared spaces and significant cultural landmarks, and places, which are highly important to local communities. Second, the reconstruction process should aim to consider the tangible significances, particularly, architectural significance, technological, spatial and decorative characteristic, besides respecting the designation values of OUV, authenticity and integrity. Third, all intangible cultural heritage domains associated with the tangible heritage in 
question should be included in the reconstruction plan, these include the domains associated with the relative communities and internationally (designation values). Thirdly, safeguarding the intangible aspects of spiritual, symbolic, pride, history, social, cultural, aesthetic and identity values should be considered as part of the reconstruction procedure. Finally, if the devastated sites under reconstruction are associated with memory, this should be investigated in the reconstruction procedure.

The second aim 'to extract useful identification of the total heritage values attributed to heritage areas' in order to provide a response to the second question raised in our introduction "what are the appropriate total values to be considered in post-conflict reconstruction/reconciliation?" was also accomplished and summarised in Table 3. The analysis shows that 10 values including, cultural, social, historical, identity, authenticity, integrity, OUV, aesthetic, economic and intangible are defined by few documents out of the 37. We observed that there is some inconsistency and ambiguity related to particular terms that would benefit from attention to clarify meaning in current policies. In particular, the recent Syrian policy, the Law for Protection, Management and Promotion of Cultural Heritage, which is in its preparation stages could benefit from this. The material presented in Table 3 is also useful in presenting an overview of the recommendations advocated in ICOMOS Guidance on Post Trauma 2017, UNESCO Warsaw Recommendation 2018 and UNESCO/World Bank Culture in City Reconstruction 2018. Additionally, further scrutiny resulted in the creation of Table 4, in which all 10 values were associated with particular tangible and intangible elements of a heritage urban landscape context.

The third aim 'to propose clarifications and guidance for sustainable reconciliation' not only provided a guide for the reconciliation process, but also potentially assists in the re-nomination process to the World heritage List. Table 3 reveals that authenticity, OUV and integrity are associated with both tangible and intangible elements of heritage; therefore, future nomination after reconstruction would be supported by responding to this finding. Moreover, as these aspects are identified for each particular value, this facilitates potential sustainable reconciliation. It also gives the opportunity to assist in addressing the challenge of reconciliation after extensive destruction through attention in particular to intangible aspects. Consequently, the final question raised "how can such reconstruction contribute to sustainable reconciliation?" is also addressed. In line with the results presented in this article, we can argue that in order to arrive at a comprehensive sustainable reconciliation, an inclusive set of heritage values, listed and defined in Table 3, should be considered throughout the reconstruction procedure. The relationships between key characteristics of the heritage in question, the values identified and the general sustainable dimensions, established in Tables 2 and 4, facilitate such understanding and implementation. Inclusively, these should be considered in the light of the responses provided to the first two research questions above.

While this paper has provided responses to the three primary research questions raised, the outcomes of an application of these issues are further explored in the supplementary paper.

The literature addressing the protection and reconstruction of cultural heritage during wartime is extensive. This includes: [46-49]. However, much of what has been written has focussed on the laws and acts of protection; whereas this paper deals with a novel support for authoritative actions to support reconciliation. This is done by addressing heritage values, derived from international heritage policies, as a key driver for post-conflict reconciliation.

Moreover, several scholars explored the associations between heritage reconstruction and SDGs from different perspectives and by the implementation of a variety of methods. Examples include [50,51]. Likewise, a number of researchers applied content analysis methodology to documents issued by UNESCO and ICOMOS to extract particular information, examples include [51,52]. The significance of this paper is twofold. First, the methodology and aggregated tables offer simplifying, and over-arching, summaries of the data, thus facilitating understanding and integration of values and reconciliation process in current and future guidance. Second, the solitary extractions from carefully selected heritage policies reinforce the official and practical implication of the results. Consequently, heritage policies could be more consistent in use of key terms. 
The methodology presented is intended to contribute to an oversight of ICOMOS's and UNESCO's debate on sustainable reconstruction/reconciliation of heritage as fundamental aspect of sustainable development. It systematically considers all elements of heritage in relation to the relevant values and sustainable dimensions. The application of the content analysis provided an opportunity to shed light on a number of overlooked criteria in particular heritage values and to pave a way for a comprehensive understanding of the links between heritage values and their constituent aspects.

These outcomes are aimed to be a useful resource for scholars and policy-makers in the areas of cultural heritage and urban development, particularly when elaborating sustainable multidisciplinary planning strategies and policies in post-conflict situations.

Author Contributions: Individual contributions were as follows "conceptualization, A.A. and A.B.; methodology, A.A.; software, A.A.; validation, A.A. and. A.B.; formal analysis, A.A.; investigation, A.A.; resources, A.A.; data curation, A.A.; writing-original draft preparation, A.A.; writing-review and editing, A.A. and A.B.; visualization, A.A.

Funding: This research received no external funding.

Acknowledgments: The first author would like to acknowledge that part of this work was undertaken when she was a CARA fellow at the University of Liverpool. She would like to express her sincere thanks to CARA (the Council for At-Risk Academics) and to the University of Liverpool for their kind and generous support, without which part of this work would not have been possible.

Conflicts of Interest: The authors declare no conflict of interest.

\section{References}

1. Van Oers, R.; Pereira Roders, A. Road map for application of the HUL approach in China. J. Cult. Herit. Manag. Sustain. Dev. 2013, 3, 4-17. [CrossRef]

2. Brosché, J.; Legnér, M.; Kreutz, J.; Ijla, A. Heritage under attack: Motives for targeting cultural property during armed conflict. Int. J. Herit. Stud. 2017, 23, 248-260. [CrossRef]

3. Roders, A.P.; Van Oers, R. World Heritage cities management. Facilities 2011, 29, 276-285. [CrossRef]

4. Legnér, M. Post-conflict reconstruction and the heritage process. J. Archit. Conserv. 2018, 24, 78-90. [CrossRef]

5. Turner, M. Culture as an Enabler for Sustainable Development: Challenges for the World Heritage Convention in Adopting the UN Sustainable Development Goals. In Going beyond Perceptions of Sustainability in Heritage Studies; Albert, M.-T., Bandarin, F., Pereira Roders, A., Eds.; Springer International Publishing: Cham, Switzerland, 2017.

6. United Nations (UN). Transforming our world. In The 2030 Agenda for Sustainable Development; United Nations: New York, NY, USA, 2015.

7. Rowney, B. Charters and the Ethics of Conservation: A Cross-Cultural Perspective. Ph.D. Thesis, The University of Adelaide, Adelaide, Australia, 2004.

8. Ahmad, Y. The Scope and Definitions of Heritage: From Tangible to Intangible. Int. J. Herit. Stud. 2006, 12, 292-300. [CrossRef]

9. Marco, L.D. Connecting Principles with Practice: From Charters to Guiding Case Studies. City Time 2009, 4, 13-21.

10. Brodie, N. Syria and its Regional Neighbors: A Case of Cultural Property Protection Policy Failure? Int. J. Cult. Prop. 2015, 22, 317-335. [CrossRef]

11. Weber, S. Reshaping Damascus: Social change and patterns of architecture in late Ottoman time. In From the Syrian Land to the States of Syria and Lebanon; Philipp, T., Schumann, C., Eds.; Orient Institute: Beirut, Lebanon, 2004; pp. 41-58. ISBN -10 3899133536.

12. UNESCO World Heritage Centre. Available online: http://whc.unesco.org/en/statesparties/sy (accessed on 28 December 2018).

13. UNESCO Intangible Cultural Heritage. Available online: https://ich.unesco.org/en/USL/shadow-play01368 (accessed on 28 December 2018).

14. Abdulkarim, M.; Kutiefan, L. State Party Report on the State of Conservation of the Syrian Cultural Heritage Sites; Syria Ministry of Culture, Directorate General of Antiquities \& Museums: Damascus, Syria, 2017. 
15. An Initial Copy Was Circulated in Local Media in 2015 and Key Chapters Are Published on the DGAM Website in Arabic, the Native Language of the First Author. Available online: http:/ /www.dgam.gov.sy/ index.php? $\mathrm{m}=307$ (accessed on 28 December 2018).

16. Lostal, M. International Cultural Heritage Law in Armed Conflict: Case-Studies of Syria, Libya, Mali, the Invasion of Iraq, and the Buddhas of Bamiyan; Cambridge University Press: Cambridge, UK, 2017; ISBN 9781316718414.

17. Bold, J.; Larkham, P.; Pickard, R. Authentic Reconstruction: Authenticity, Architecture and the Built Heritage; Bloomsbury 3PL: London, UK, 2018; ISBN -10 147428406X.

18. Rodwell, D. Conservation and Sustainability in Historic Cities, 1st ed.; Wiley-Blackwell: Oxford, UK, 2008; ISBN 101405126566.

19. UNESCO. Available online: http://www.unesco.org/new/en/united-nations-educational-scientific-andcultural-organization/about-us/who-we-are/introducing-unesco/ (accessed on 28 December 2018).

20. UNESCO World Heritage Committee. In Proceedings of the Decisions Adopted During the 40th Session of the World Heritage Committee (Istanbul, 2016), Paris, France, 10-20 July 2016; UNESCO: Paris, France, 2016. Available online: https://whc.unesco.org/archive/2016/whc16-40com-19-en.pdf (accessed on 28 December 2018).

21. UNESCO World Heritage Centre. Warsaw Recommendation on Recovery and Reconstruction of Cultural Heritage; UNESCO: Paris, France, 2018; Available online: https://whc.unesco.org/en/news/1826 (accessed on 28 December 2018).

22. ICOMOS. Discussion Paper: Evaluations of World Heritage Nominations Related to Sites Associated with Memories of Recent Conflicts; ICOMOS: Paris, France, 2018; Available online: https: //www.icomos.org/images/DOCUMENTS/World_Heritage/ICOMOS_Discussion_paper_Sites_ associated_with_Memories_of_Recent_Conflicts.pdf (accessed on 27 December 2018).

23. UNESCO. International Coalition of Sites of Conscience. In Interpretation of Sites of Memory; UNESCO: Paris, France, 2018.

24. Hsieh, H.-F.; Shannon, S.E. Three Approaches to Qualitative Content Analysis. Qual. Health Res. 2005, 15, 1277-1288. [CrossRef] [PubMed]

25. Bernard, H.R.; Wutich, A.Y.; Ryan, G.W. Analysing Qualitative Data: Systematic Approaches, 2nd ed.; SAGE Publications: Thousand Oaks, CA, USA, 2016; ISBN 109781483344386.

26. Mason, R. Assessing values in conservation planning: Methodological Issues and Choices. In Assessing the Values of Cultural Heritage; de la Torre, M., Ed.; Getty Conservation Institute: Los Angeles, CA, USA, 2002.

27. Bold, J. Guidance on Heritage Assessment; Council of Europe: Strasbourg, France, 2005.

28. UNESCO. Intangible Cultural Heritage and Sustainable Development. Available online: https://ich.unesco. org/doc/src/34299-EN.pdf (accessed on 27 December 2018).

29. ICOMOS. The Paris Declaration On Heritage As a Driver of Development. 2011. Available online: https://www.icomos.org/Paris2011/GA2011_Declaration_de_Paris_EN_20120109.pdf (accessed on 27 December 2018).

30. United Nations Educational, Scientific and Cultural Organization (UNESCO). Hangzhou Declaration: Placing Culture at the Heart of Sustainable Development; UNESCO: Hangzhou, China, 2013.

31. UNESCO. Operational Guidelines for the Implementation of the World Heritage Convention; UNESCO: Paris, France, 2017.

32. Feilden, B.M.; Jokilehto, J. Management Guidelines for World Cultural Heritage Sites, 2nd ed.; ICCROM; UNESCO; ICOMOS: Rome, Italy, 1998.

33. ICOMOS. New Zealand Charter for the Conservation of Places of Cultural Heritage Value; ICOMOS: Auckland, New Zealand, 2010; Available online: https://www.icomos.org/images/DOCUMENTS/Charters/ICOMOS_ NZ_Charter_2010_FINAL_11_Oct_2010.pdf (accessed on 27 December 2018).

34. ICOMOS. Burra Charter for the Conservation of Places of Cultural Significance; ICOMOS: Burra, Australia, 2013; Available online: https:/ / australia.icomos.org/wp-content/uploads/The-Burra-Charter-2013-Adopted31.10.2013.pdf (accessed on 27 December 2018).

35. ICOMOS. The Nara Document on Authenticity; ICOMOS: Paris, France, 1996; Available online: https:/ / www. icomos.org/charters/nara-e.pdf (accessed on 27 December 2018).

36. ICOMOS. The Burra Charter: The Australia ICOMOS Charter for Places of Cultural Significance; ICOMOS: Burra, Australia, 1999; Available online: https:/ / australia.icomos.org/wp-content/uploads/BURRA_CHARTER. pdf (accessed on 27 December 2018). 
37. Bureau Krakow. The Charter of Krakow Principles for Conservation and Restoration of Built Heritage; ICOMOS: Krakow, Poland, 2000; Available online: http://smartheritage.com/wp-content/uploads/2015/ 03/KRAKOV-CHARTER-2000.pdf (accessed on 27 December 2018).

38. United Nations Educational, Scientific and Cultural Organization (UNESCO). Vienna Memorandum on World Heritage and Contemporary Architecture - Managing the Historic Urban Landscape; UNESCO: Vienna, Austria, 2005.

39. ICOMOS. Guidance on Post Trauma Recovery \& Reconstruction for World Cultural Heritage Properties; ICOMOS: Paris, France, 2017; Available online: http:/ / openarchive.icomos.org/1763/19/ICOMOS\%20Guidance\% 20on\%20Post\%20Trauma\%20Recovery\%20.pdf (accessed on 27 December 2018).

40. ICOMOS. Guidance on Heritage Impact Assessments for Cultural World Heritage Properties; ICOMOS: Paris, France, 2011; Available online: https://www.icomos.org/world_heritage/HIA_20110201.pdf (accessed on 27 December 2018).

41. ICOMOS. Declaration of San Antonio: Authenticity in the Conservation and Management of the Cultural Heritage; ICOMOS: Paris, France, 1996/2011; Available online: https:/ /www.icomos.org/en/resources/charters-andtexts /179-articles-en-francais / ressources / charters-and-standards/188-the-declaration-of-san-antonio (accessed on 27 December 2018).

42. United Nations Educational, Scientific and Cultural Organization (UNESCO). Integration of a Sustainable Development Perspective into the Processes of the World Heritage Convention; UNESCO: Paris, France, 2015.

43. United Nations Educational, Scientific and Cultural Organization (UNESCO). Recommendation on the Safeguarding of Traditional Culture and Folklore; UNESCO: Paris, France, 1989.

44. United Nations Educational, Scientific and Cultural Organization (UNESCO). Convention for the Safeguarding of Intangible Cultural Heritage; UNESCO: Paris, France, 2003.

45. International Council on Monuments and Sites (ICOMOS). Québec Declaration on the Preservation of the Spirit of Place; ICOMOS: Québec, QB, Canada, 2008; Available online: https://whc.unesco.org/uploads/activities/ documents/activity-646-2.pdf (accessed on 27 December 2018).

46. Frulli, M. The Criminalization of Offences against Cultural Heritage in Times of Armed Conflict: The Quest for Consistency. Eur. J. Int. Law 2017, 22, 203-217. [CrossRef]

47. Layton, R.; Stone, P.; Thomas, J. Destruction and Conservation of Cultural Property; Routledge: London, UK, 2011; ISBN 109780415510684.

48. Albro, R.; Ivey, B. Cultural Awareness in the Military: Developments and Implications for Future Humanitarian Cooperation, 1st ed.; Palgrave Pivot: Hampshire, UK, 2014.

49. Isakhan, B.; José, A.; Zarandona, G. Layers of religious and political iconoclasm under the Islamic State: Symbolic sectarianism and pre-monotheistic iconoclasm. Int. J. Herit. Stud. 2018, 24, 1-16. [CrossRef]

50. Guzman, P.; Pereira Roders, A.R.; Colenbrander, B. Impacts of common urban development factors on cultural conservation in world heritage cities: An indicators-based analysis. Sustainability 2018, 10, 853. [CrossRef]

51. Rodwell, D. The Historic Urban Landscape and the Geography of Urban Heritage. Hist. Environ. Policy Pract. 2018. [CrossRef]

52. Alsalloum, A. Heritage-led Sustainable Urban Regeneration: The Development of an Assessment Model for World Heritage Sites Cities. Ph.D. Thesis, University of Liverpool, Liverpool, UK, 2011.

(C) 2019 by the authors. Licensee MDPI, Basel, Switzerland. This article is an open access article distributed under the terms and conditions of the Creative Commons Attribution (CC BY) license (http:/ / creativecommons.org/licenses/by/4.0/). 